\title{
Water Insecurity is Associated with Lack of Viral Suppression and Greater Odds of AIDS-Defining Illnesses Among Adults with HIV in Western Kenya
}

\author{
Jason M. Nagata, ${ }^{1}\left(\mathbb{D}\right.$. Joshua D. Miller ${ }^{3}$ (1) . Craig R. Cohen ${ }^{4}$ Edward A. Frongillo ${ }^{5}$ Elly Weke ${ }^{6} \cdot$ Rachel Burger $^{4}$. \\ Pauline Wekesa ${ }^{6}$. Lila A. Sheira ${ }^{7}$. A. Rain Mocello ${ }^{4}$ Phelgona Otieno ${ }^{8}$ - Lisa M. Butler ${ }^{9}$. Elizabeth A. Bukusi ${ }^{4,6}$. \\ Sheri D. Weiser ${ }^{7} \cdot$ Sera L. Young ${ }^{10,11}$
}

Accepted: 26 July 2021 / Published online: 9 August 2021

(c) The Author(s) 2021

\begin{abstract}
Reliable access to safe and acceptable water in sufficient quantities (i.e., water security) is important for medication adherence and limiting pathogen exposure, yet prior studies have only considered the role of food security as a social determinant of HIV-related health. Therefore, the objective of this analysis was to assess the relationships between household water insecurity and HIV-related outcomes among adults living with HIV in western Kenya $(\mathrm{N}=716)$. We conducted a cross-sectional analysis of baseline data from Shamba Maisha (NCT02815579), a cluster randomized controlled trial of a multisectoral agricultural and asset loan intervention. Baseline data were collected from June 2016 to December 2017. We assessed associations between water insecurity and HIV-related outcomes, adjusting for clinical and behavioral confounders, including food insecurity. Each five-unit higher household water insecurity score (range: 0-51) was associated with 1.21 higher odds of having a viral load $\geq 1000$ copies/mL (95\% CI 1.07, 1.36) and 1.26 higher odds of AIDS-defining illness (95\% CI 1.11, 1.42). Household water insecurity was not associated with CD4 cell count (B: 0.27 ; 95\% CI -3.59, 13.05). HIV treatment and support programs should consider assessing and addressing water insecurity in addition to food insecurity to optimize HIV outcomes.
\end{abstract}

Keywords Water insecurity $\cdot$ Food insecurity $\cdot$ Human immunodeficiency virus $\cdot$ AIDS $\cdot$ Kenya

\section{Resumen}

El acceso seguro al agua potable en cantidades suficientes (es decir, seguridad hídrica) es importante para la adherencia a la medicación y para limitar la exposición a patógenos; sin embargo, estudios anteriores solo han considerado el papel de la seguridad alimentaria como un determinante social de salud relacionado con el VIH. Por lo tanto, el objetivo de este análisis fue evaluar las relaciones entre la inseguridad hídrica en hogares y los resultados relacionados con el VIH en adultos que viven con VIH en el oeste de Kenia $(\mathrm{N}=716)$. Realizamos un análisis transversal de los datos basales de la iniciativa Shamba

Jason M. Nagata

jason.nagata@ucsf.edu

1 Department of Pediatrics, University of California, 550 16th Street, Box 0110, San Francisco, CA 94158, USA

2 Institute for Global Health Sciences, University of California, San Francisco, CA, USA

3 Department of Nutrition, University of North Carolina at Chapel Hill, Chapel Hill, NC, USA

4 Department of Obstetrics, Gynecology \& Reproductive Sciences, University of California, San Francisco, CA, USA

5 Department of Health Promotion, Education, and Behavior, University of South Carolina, Columbia, SC, USA
6 Centre for Microbiology Research, Kenya Medical Research Institute, Nairobi, Kenya

7 Department of Medicine, University of California, San Francisco, CA, USA

8 Centre for Clinical Research, Kenya Medical Research Institute, Nairobi, Kenya

9 Institute for Collaboration On Health, Intervention and Policy, University of Connecticut, Storrs, CT, USA

10 Department of Anthropology, Northwestern University, Evanston, IL, USA

11 Institute for Policy Research, Northwestern University, Evanston, IL, USA 
Maisha (NCT02815579), un ensayo controlado aleatorio por conglomerados de una intervención multisectorial de créditos para insumos agrícolas. Los datos basales se recopilaron de junio de 2016 a diciembre de 2017. Evaluamos las asociaciones entre la inseguridad hídrica y resultados relacionados con el VIH, ajustando por factores de confusión clínicos y conductuales, incluyendo inseguridad alimentaria. Cada cinco unidades superiores de puntajes de inseguridad hídrica doméstica (rango: 0-51) fue asociado con 1.21 mayores probabilidades de tener una carga viral más alta $\geq 1000$ copias / $\mathrm{ml}$ (CI 95\%: 1,07-1,36) y con 1.26 mayores probabilidades de factores determinantes del SIDA (CI 95\%: 1,11-1,42). La inseguridad de hídrica doméstica no se asoció con el recuento de células CD4 (B: -0,27; CI 95\%: -13,59-13,05). Los programas de tratamiento y de apoyo al VIH deben considerar evaluar y abordar la inseguridad hídrica además de la inseguridad alimentaria para optimizar los resultados del VIH.

Palabras clave Inseguridad hídrica $\cdot$ Inseguridad alimentaria $\cdot$ Virus de inmunodeficiencia humana $\cdot$ SIDA $\cdot$ Kenia

\section{Introduction}

Global water crises present substantial threats to human health and economic productivity [1]. Currently, at least four billion people experience severe water scarcity each year [2]. Issues with water availability (including both shortage and excess), access, quality, and acceptability [2-4] will become more severe in the coming decades due to climate and population change, conflict, and inequitable resource distribution [5].

Problems with water are common in regions with high HIV prevalence (e.g., sub-Saharan Africa), although few studies have considered both conditions concurrently [6-8]. Understanding the relationship between water insecurity, i.e. the inability to access adequate and safe water for a healthy and productive life [3], and HIV-related outcomes is thus critical for addressing these often co-occurring epidemics [9].

Water insecurity is distinct from, but related to, food insecurity (i.e., the inability to access sufficient nutritious foods) and poverty $[6,7,10-12]$. Food insecurity is a critical social determinant of health, including HIV-related clinical outcomes [13-16]. Food insecurity increases an individual's risk of malnutrition, depression, and anxiety [17-20]; these conditions can limit the ability of individuals to access health care services and lower adherence to antiretroviral therapy (ART) regimens, which are in turn associated with higher viral loads, lack of sustained viral suppression, and lower CD4 cell counts [13, 21-23]. Although water insecurity may be a similarly critical health determinant, few data have linked water insecurity to HIV-related outcomes [8]. Further, water insecurity may be a driver of food insecurity since water is required for food production and preparation $[6,11,24]$, such that water insecurity may both directly and indirectly undermine well-being $[25,26]$.

Our objective was to determine the association between household water insecurity and HIV-related outcomes among food-insecure adults living with HIV in Kenya. We hypothesized that greater household water insecurity would be associated with worse HIV-related health outcomes among people living with HIV, even after accounting for food insecurity.

\section{Methods}

\section{Participants and Study Design}

We analyzed baseline data from Shamba Maisha (NCT02815579), a cluster randomized clinical trial designed to test if an agricultural intervention improved food security and HIV-related health outcomes. The study was conducted in Kisumu, Homa Bay, and Migori counties in Kenya, where the prevalence of both food insecurity and HIV are high [27]. Individuals were eligible if they were between 18 and 60 years of age, living with HIV, enrolled in HIV care, receiving antiretroviral therapy, food insecure [met criteria for moderate or severe food insecurity using the Household Food Insecurity Access Scale [12] and/or malnourished $(\mathrm{BMI}<18.5)$ the year prior to enrollment, had access to farmland with adjacent surface water, and agreed to save for a down payment for a loan for farming commodities. Baseline data for the larger study were collected at one home and one clinic visit (among 16 clinics) between June 2016 and December 2017. Of the 720 study participants enrolled, 716 had complete water insecurity data and were included for this secondary analysis. All participants provided written informed consent. Ethical approval was provided by the Institutional Review Boards at the University of California, San Francisco, and Kenya Medical Research Institute. Trained research assistants conducted structured interviews in the local languages (Dholuo or Swahili) or English at the health facility and at participants' farms or homes using a handheld computer tablet for data collection using Open Data Kit Collect [28].

\section{Measures}

\section{Water Insecurity}

Household water insecurity in the prior month was measured using a preliminary version of a scale that was developed and later validated for this region [29]. The scale captures multiple components of water insecurity, including availability, accessibility, and use. The implemented version did 
not contain 3 of the items from the 20-item scale (feeling angry about one's water situation, missing meetings due to water insufficiency, and missing meetings due to lack of water for bathing) because these items had not yet been finalized. Response options were never (scored as 0 ), rarely (1), sometimes (2), or often/always (3) and were summed together (range: $0-51$ ). The modified scale had high internal consistency (Cronbach's alpha $=0.89)$.

\section{Viral Load}

HIV RNA testing was performed on venous blood using the COBAS TaqMan HIV viral load platform (Roche Molecular Diagnostics, Pleasanton, CA). Viral load was dichotomized into $\geq 1000$ vs $<1000$ copies/mL based on the WHO definition of virologic failure [30]. In a sensitivity analysis, we also examined viral load $\geq 200$ vs $<200$ copies/mL given negligible HIV transmission below this cutoff [31].

\section{CD4 Cell Count}

Absolute CD4 T lymphocyte cell count testing (cells/ $\mathrm{mL}$ ) was performed on blood from a fingerstick or venous sample using the BD FACSCount (BD Bioscience, San Jose, CA) or PIMA assay (Alere Inc., Waltham, Maryland, USA).

\section{AIDS-Defining Illnesses}

Data on AIDS-defining illnesses were abstracted from participants' medical records [32]. Individuals were classified as having an AIDS-defining illness if they experienced any of the following in the past six months: candidiasis of esophagus, bronchi, trachea, or lung; invasive cervical cancer; extrapulmonary cryptococcosis; HIV-related encephalopathy; herpes simplex; chronic ulcers or bronchitis, pneumonitis, or esophagitis; Kaposi sarcoma; lymphoma; mycobacterium tuberculosis; mycobacterium (other or unidentified species, disseminated or extrapulmonary); pneumocystis pneumonia; recurrent pneumonia; progressive multifocal leukoencephalopathy; toxoplasmosis of brain; or wasting syndrome due to HIV [32].

\section{Covariates}

Participants' age, sex, household size, time since initiation of antiretroviral therapy (ART), and month of interview were collected. Household wealth was derived using a principal components analysis of a household's ownership of assets and dwelling characteristics (roof materials, sanitation facilities) using methods from the Demographic and Health Surveys [33]. Household food insecurity in the prior 30 days was based on the 9-item Household Food Insecurity Access Scale (range: 0-27) [12], a measure that has been crossculturally validated and previously used among adults living with HIV in Kenya [6, 34-36].

\section{Statistical Analysis}

Data analysis was performed using Stata 15.1 (StataCorp, College Station, TX). We used multiple regression to determine the association between every five-unit higher household water insecurity score (for ease of interpretation) and outcomes of interest: viral load $\geq 1000$ (logistic regression), CD4 count (linear regression, distribution was not highly skewed), and any AIDS-defining illness (logistic regression). Each association was assessed with and without food insecurity as a covariate. All models adjusted for sex, age,
Table 1 Baseline

sociodemographic and HIVrelated health characteristics of participants in the Shamba Maisha study $(\mathrm{N}=716)$

\begin{tabular}{ll}
\hline Sociodemographic characteristics & Total \\
& $\mathrm{N}=716$ \\
\hline Age (years), median (IQR) & $40(34,47)$ \\
Sex, n (\%) & $395(55.2 \%)$ \\
Female & $321(44.8 \%)$ \\
Male & $6(5,8)$ \\
Household size, median (IQR) & $1.7(0.6)$ \\
Household wealth, mean (SD) & \\
Household water insecurity score (0-51), mean (SD) & $5.9(7.1)$ \\
Household food insecurity score (0-27), mean (SD) & $12.5(4.2)$ \\
HIV Outcomes & \\
Time since antiretroviral therapy initiation (years), mean (SD) & $5.0(2.9)$ \\
Viral load $>1000($ copies/mL), n (\%) & $72(10.1 \%)$ \\
CD4 Count (cells/mm $\left.{ }^{3}\right)$ & $582.6(258.0)$ \\
Any AIDS-defining illness & $35(4.9 \%)$ \\
\hline
\end{tabular}

aDerived from a principal component analysis of self-reported asset ownership (range: 0.1-2.6) 
household size, wealth, and time since ART initiation, and accounted for clustering of facilities using a sandwich estimator. We examined season by including month of interview as a covariate and found no meaningful differences in estimated associations, such that we did not include it in the final models.

\section{Results}

Of the 716 adults, $55.2 \%$ were female; the median age was 40 years (Table 1) and the median household size was six individuals. Water insecurity was low in this population (mean score: 5.9 ). As for HIV characteristics, $10.1 \%$ had a viral load $\geq 1000$ copies/mL ( $15.9 \%$ with viral load $\geq 200$ copies $/ \mathrm{mL}$ ), and $4.9 \%$ had an AIDS-defining illness. The mean CD4 count was 582 cells $/ \mathrm{mL}$.

Unadjusted associations with HIV outcomes are shown in Appendix A. Water insecurity was associated with HIVrelated outcomes in multivariable models (Table 2, Appendix B for effect estimates of all covariates). Each five-unit higher household water insecurity score was associated with 1.21 higher odds of having a viral load $\geq 1000(95 \%$ CI 1.07-1.36, $\mathrm{p}=0.003$ ) and 1.26 higher odds of a recent AIDS-defining illness (95\% CI 1.11-1.42, p <0.001). Magnitudes of association were similar after adjusting for household food insecurity. Household water insecurity was not associated with CD4 cell count in either model. In a sensitivity analysis, each five-unit higher water insecurity score was associated with 1.10 higher odds of having a viral load $\geq 200$ (95\% CI $0.90-1.35, \mathrm{p}=0.336$ ). In additional sensitivity analyses, water insecurity was not associated with CD4 count when dichotomized into clinically relevant threshold values (e.g. $>200,>350$, or $>500$ cells/ $\mathrm{mL}$ ).

\section{Discussion}

Greater household water insecurity was associated with worse HIV-related outcomes among adults living with HIV in Kenya. Specifically, after controlling for food insecurity, water insecurity was associated with higher odds of having a viral load $\geq 1000$ and having a recent AIDSdefining illness. This builds on prior findings that food insecurity is associated with worse HIV-related outcomes [13-15], and highlights the distinct importance of water insecurity when food insecurity is accounted for.

A number of plausible mechanisms may explain the association between water insecurity and poor HIV-related health. Water insecurity may lead to dehydration and fatigue [4], as well as exacerbate opportunistic infections including diarrheal or skin diseases (e.g., from waterborne infections) [37], especially when an individual's ability to engage in hygiene practices like regular handwashing is limited $[9,37]$. Subsequent AIDS-defining illnesses may in turn limit an individual's ability to follow up with medical care, which can lead to incomplete viral load suppression. Water insecurity is also associated with greater stress and worse mental health [6, 8, 38], which can exacerbate ART adherence and clinical follow-up, leading to incomplete viral load suppression [9, 39]. Further, the opportunity costs and injuries associated with acquiring water may limit an individual's ability to seek clinical care [40, 41]. People without adequate water may skip antiretroviral medication doses if they are unable to swallow medications dry or prepare foods that reduce side effects associated with medications [9,34]. These potential mechanisms should be empirically tested in future studies.

The relationship between HIV and water insecurity may be bidirectional, as is the case with food insecurity [16]. People with worse HIV outcomes or AIDS-defining

Table 2 Associations between water insecurity and HIV-related outcomes at baseline in the Shamba Maisha study $(\mathrm{N}=716)$

\begin{tabular}{|c|c|c|c|c|c|c|}
\hline & \multicolumn{2}{|l|}{ Viral load > 1000} & \multicolumn{2}{|l|}{ CD4 count } & \multicolumn{2}{|c|}{ AIDS-defining illness } \\
\hline & $\mathrm{aOR}(95 \% \mathrm{CI})$ & $\mathrm{p}$ & B $(95 \%$ CI $)$ & $\mathrm{p}$ & $\mathrm{aOR}(95 \% \mathrm{CI})$ & $\mathrm{p}$ \\
\hline \multicolumn{7}{|c|}{ Model with water insecurity only } \\
\hline Water insecurity & $1.21(1.07,1.36)$ & 0.003 & $-0.27(-13.59,13.05)$ & 0.966 & $1.26(1.11,1.42)$ & $<0.001$ \\
\hline \multicolumn{7}{|c|}{$\begin{array}{l}\text { Model with water insecurity and food } \\
\text { insecurity }\end{array}$} \\
\hline Water insecurity & $1.16(1.00,1.33)$ & 0.044 & $0.73(-13.28,14.75)$ & 0.913 & $1.29(1.10,1.51)$ & 0.002 \\
\hline Food insecurity & $1.07(0.99,1.15)$ & 0.074 & $-1.429(-6.90,4.05)$ & 0.586 & $0.96(0.90,1.04)$ & 0.348 \\
\hline
\end{tabular}

Bold indicates $\mathrm{p}<0.05$

$a O R$ adjusted odds ratio from logistic regression, $B$ coefficient from linear regression

Models include sex, age, household size, wealth, time since ART initiation, and account for clustering at the facility level. Water insecurity is scaled per five units 
illnesses may require more frequent health care visits, which can result in greater health care costs that divert resources from water acquisition (e.g., time to fetch water, capital to purchase water storage containers or water treatment technologies) [9, 42]. As HIV illness severity worsens, people may be less able to work and to generate income or travel to acquire water [9, 43]. Further, more water may be needed to maintain hygiene as health worsens $[9,44]$. All of these mechanisms should also be investigated empirically.

Water insecurity was not associated with CD4 count, contrary to our hypothesis. This was surprising given the positive association between water insecurity and AIDSdefining illness, and that AIDS-defining illness is often related to CD4 count [32]. Water insecurity and poor sanitation, however, may lead to higher risk of AIDSdefining illnesses at every CD4 level. It is possible that a one-month recall period for water insecurity was too short to see associations with CD4 count.

Several limitations of the study should be noted. The design was cross-sectional, limiting causal inference. Although we adjusted for wealth and other potential confounders, unmeasured confounders may remain unaccounted for. The study would have been further improved with implementation of the final version of the Kenyan water insecurity scale [29]; future studies may consider using a cross-culturally validated household water insecurity scale to enable comparisons across settings [10]. Because of the study inclusion criteria, these findings may not be generalizable to other populations. The study sample, however, represents vulnerable and marginalized people who are at risk of water insecurity and poor HIV outcomes. The magnitude of association between water insecurity and incomplete viral load suppression was closer to the null using a cutoff of $\geq 200$ compared to $\geq 1000$, although there was greater error in our estimation and potentially lower assay sensitivity of the former. Strengths included a large sample of a hard-to-reach and under-investigated population, use of validated measures, and collection of biological data.

In conclusion, greater water insecurity was associated with poorer HIV-related outcomes among adults living with HIV in Kenya after controlling for food insecurity and other confounders. This relationship has important public health and clinical implications, the most important of which is that HIV treatment and support programs should consider assessing and addressing water insecurity in addition to food insecurity to optimize HIV outcomes. Future research should examine the relationships between water insecurity and HIV outcomes longitudinally as well as evaluate the impact that interventions to reduce water insecurity has on health and well-being, including HIV outcomes.
Supplementary Information The online version supplementary material available at https://doi.org/10.1007/s10461-021-03410-w.

Acknowledgements We thank the Kenyan women and men who generously gave their time to participate in the study. We acknowledge the important support of the Kenyan Medical Research Institute (KEMRI), the University of California, San Francisco (UCSF), and Global Programs for Research and Training (GPRT). We would also like to recognize the Director of KEMRI, the Director of KEMRI's Centre for Microbiology Research, and the Kisumu, Homa Bay, and Migori County Ministries of Health for their support in conducting this research. We acknowledge the content expertise and support received from the UC Global Health Institute's Center of Expertise in Women's Health and Empowerment. We also thank Omar Sajjad, Bernard Rono, Brian Polo, Phoebe Olugo, Sylvia Atieno, Maureen Nyaura, Sylvia Akoko, Titus Arunga, Belinda Odhiambo, Richard Omondi, Elly Bwana, Emmanuel Otieno, Julie Omoro, Doreen Otieno, Rose Ngwengi, Amos Onyango, Sharon, Owour, Pius Atonga, Fredrick Ouko, Nicholas Ambira, George Kennedy, Geoffery Ojuok, Risper Omollo, Elija Mbaja, Valiant Odhiambo, Peter Obando, and Julias Odhacha for their important contributions to this research. We thank Samuel Benabou and Ananya Rupanagunta for editorial assistance.

Authors' contributions JMN, JDM, and SLY - conceptualization, analysis, writing, critical feedback, and editing. CRC, EAF, LMB, EAB, SDW - conceptualization, critical feedback, and editing. EW, RB, PW, LAS, ARM, PO—data collection, data cleaning, and editing.

Funding The research described was financially supported by the National Institutes of Mental Health under Grant 1R01MH107330 and the Competitive Research Grants to Develop Innovative Methods and Metrics for Agriculture and Nutrition Actions (IMMANA). IMMANA is funded with UK Aid from the UK government. SLY was supported by the Andrew Carnegie Fellows Program and the generous support of the American people provided to Rutgers University and the Feed the Future Sustainable Intensification Innovation Lab through the United State Agency for International Development Cooperative Agreement AID-OAA-L-14-00006 to SLY. The views and conclusions contained herein are those of the authors and should not be interpreted as necessarily representing the official policies or endorsements, either expressed or implied, of the National Institutes of Health or the US Government. Funders of the study had no role in study design, data collection, data analysis, data interpretation or writing of the report. Authors had full access to all study data and had final responsibility for the decision to submit for publication.

Data Availability Data are available on request.

Code Availability Code is available upon request.

\section{Declarations}

Conflict of interest No conflicts of interest or financial disclosures were reported by the authors of this paper.

Ethical Approval Ethical approval was provided by the Institutional Review Boards at the University of California, San Francisco, and Kenya Medical Research Institute.

Consent to Participate All study participants provided written informed consent. 
Open Access This article is licensed under a Creative Commons Attribution 4.0 International License, which permits use, sharing, adaptation, distribution and reproduction in any medium or format, as long as you give appropriate credit to the original author(s) and the source, provide a link to the Creative Commons licence, and indicate if changes were made. The images or other third party material in this article are included in the article's Creative Commons licence, unless indicated otherwise in a credit line to the material. If material is not included in the article's Creative Commons licence and your intended use is not permitted by statutory regulation or exceeds the permitted use, you will need to obtain permission directly from the copyright holder. To view a copy of this licence, visit http://creativecommons.org/licenses/by/4.0/.

\section{References}

1. World Economic Forum. The Global Risks Report 2020, 15th Edition [Internet]. Geneva, Switzerland: World Economic Forum; 2020. Available from: https://www.weforum.org/reports/ the-global-risks-report-2020

2. Mekonnen MM, Hoekstra AY. Four billion people facing severe water scarcity. Sci Adv. 2016;2(2):e1500323-e1500323.

3. Wutich A. Water insecurity: An agenda for research and call to action for human biology. Am J Hum Biol. 2020;32(1):e23345.

4. Rosinger AY, Young SL. The toll of household water insecurity on health and human biology: Current understandings and future directions. WIREs Water. 2020;7(6):e1468.

5. Greve P, Kahil T, Mochizuki J, Schinko T, Satoh Y, Burek P, et al. Global assessment of water challenges under uncertainty in water scarcity projections. Nat Sustain. 2018;1(9):486-94.

6. Boateng G, Workman C, Miller J, Onono M, Neilands T, Young $\mathrm{S}$. The syndemic effects of food insecurity, water insecurity, and HIV on depressive symptomatology among Kenyan women. Soc Sci Med. 2020;15:113043.

7. Miller JD, Frongillo EA, Weke E, Burger R, Wekesa P, Sheira LA, et al. Household water and food insecurity are positively associated with poor mental and physical health among adults living with HIV in Western Kenya. J Nutr. 2021;151(6):1656-64.

8. Workman CL, Ureksoy H. Water insecurity in a syndemic context: Understanding the psycho-emotional stress of water insecurity in Lesotho. Africa Soc Sci Med. 2017;179:52-60.

9. West BS, Hirsch JS, El-Sadr W. HIV and H2O: Tracing the connections between gender, water and HIV. AIDS Behav. 2013;17(5):1675-82.

10. Young S, Boateng G, Jamaluddine Z, Miller J, Frongillo E, Neilands $\mathrm{T}$, et al. The Household Water InSecurity Experiences (HWISE) Scale: development and validation of a household water insecurity measure for low- and middle-income countries. BMJ Glob Heal. 2019;4(5):e001750.

11. Brewis A, Workman C, Wutich A, Jepson W, Young S, et al. Household water insecurity experiences - research coordination network (HWISE-RCN), Household water insecurity is strongly associated with food insecurity: Evidence from 27 sites in low- and middle-income countries. Am J Hum Biol. 2020;32(1):e23309.

12. Coates J, Swindale A, Bilinsky P (2007) Household food insecurity access scale (HFIAS) for measurement of food access: indicator guide [Internet]. Washington, D.C.: Food and Nutrition Technical Assistance Project, Academy for Educational Development; 2007. Available from: https://www.fantaproje ct.org/monitoring-and-evaluation/household-food-insec urity-access-scale-hfias

13. Aibibula W, Cox J, Hamelin A-M, Mamiya H, Klein MB, Brassard P. Food insecurity and low CD4 count among HIV-infected people: a systematic review and meta-analysis. AIDS Care. 2016;28(12):1577-85.

14. Frega R, Duffy F, Rawat R, Grede N. Food insecurity in the context of HIV/AIDS: a framework for a new era of programming. Food Nutr Bull. 2010;31(4_suppl4):S292-312.

15. Anema A, Vogenthaler N, Frongillo EA, Kadiyala S, Weiser SD. Food insecurity and HIV/AIDS: current knowledge, gaps, and research priorities. Curr HIV/AIDS Rep. 2009;6(4):224-31.

16. Weiser SD, Young SL, Cohen CR, Kushel MB, Tsai AC, Tien $\mathrm{PC}$, et al. Conceptual framework for understanding the bidirectional links between food insecurity and HIV/AIDS. Am J Clin Nutr. 2011;94(6):1729S-1739S.

17. Singer AW, Weiser SD, McCoy SI. Does food insecurity undermine adherence to antiretroviral therapy? A Systematic Review AIDS Behav. 2015;19(8):1510-26.

18. Kalichman SC, Grebler T, Amaral CM, McKerney M, White D, Kalichman MO, et al. Food insecurity and antiretroviral adherence among HIV positive adults who drink alcohol. J Behav Med. 2014;37(5):1009-18.

19. Weiser SD, Tuller DM, Frongillo EA, Senkungu J, Mukiibi $\mathrm{N}$, Bangsberg DR. Food insecurity as a barrier to sustained antiretroviral therapy adherence in uganda. PLoS ONE. 2010;5(4):e10340.

20. Leddy AM, Sheira LA, Tamraz B, Sykes C, Kashuba ADM, Wilson TE, et al. Food insecurity is associated with lower levels of antiretroviral drug concentrations in hair among a cohort of women living with HIV in the United States. Clin Infect Dis. 2020;71(6): 1517-23.

21. McMahon JH, Wanke CA, Elliott JH, Skinner S, Tang AM. Repeated assessments of food security predict CD4 change in the setting of antiretroviral therapy. JAIDS J Acquir Immune Defic Syndr. 2011;58(1):60-3.

22. Weiser SD, Palar K, Frongillo EA, Tsai AC, Kumbakumba E, dePee $\mathrm{S}$, et al. Longitudinal assessment of associations between food insecurity, antiretroviral adherence and HIV treatment outcomes in rural Uganda. AIDS. 2014;28(1):115-20.

23. Koss CA, Natureeba P, Nyafwono D, Plenty A, Mwesigwa J, Nzarubara B, et al. Food insufficiency is associated with lack of sustained viral suppression among HIV-infected pregnant and breastfeeding ugandan women. JAIDS J Acquir Immune Defic Syndr. 2016;71(3):310-5.

24. Falkenmark M. Growing water scarcity in agriculture: future challenge to global water security. Philos Trans R Soc A Math Phys Eng Sci. 2013;371(2002):20120410.

25. Miller JD, Workman CL, Panchang SV, Sneegas G, Adams EA, Young SL, et al. Water security and nutrition: current knowledge and research opportunities. Adv Nutr. 2021;00:1-15. https://doi.org/10.1093/advances/nmab075/6322255.

26. Young SL, Frongillo EA, Jamaluddine Z, Melgar-Quiñonez H, Pérez-Escamilla R, Ringler C, et al. Perspective: the importance of water security for ensuring food security, good nutrition, and well-being. Adv Nutr. 2021. https://doi.org/10.1093/advances/ nmab003/6144691.

27. Alvarez GG, Miller JD, Santoso MV, Wekesa P, Owuor PM, Onono M, et al. Prevalence and covariates of food insecurity across the first 1000 days among women of mixed hiv status in Western Kenya: a longitudinal perspective. Food Nutr Bull. 2021;20:379572121999024.

28. Hiarlaithe MO, Grede N, de Pee S, Bloem M. Economic and social factors are some of the most common barriers preventing women from accessing maternal and newborn child health $(\mathrm{MNCH})$ and prevention of mother-to-child transmission (PMTCT) services: a literature review. AIDS Behav. 2014;18:516-30.

29. Boateng GO, Collins SM, Mbullo P, Wekesa P, Onono M, Neilands TB, et al. A novel household water insecurity scale: 
Procedures and psychometric analysis among postpartum women in western Kenya Gnambs T, editor. PLoS ONE. 2018;13(6):e0198591.

30. McCluskey SM, Boum Y, Musinguzi N, Haberer JE, Martin JN, Hunt PW, et al. Appraising Viral Load Thresholds and Adherence Support Recommendations in the World Health Organization Guidelines for Detection and Management of Virologic Failure. J Acquir Immune Defic Syndr. 2017;76(2):183-7.

31. LeMessurier J, Traversy G, Varsaneux O, Weekes M, Avey MT, Niragira O, et al. Risk of sexual transmission of human immunodeficiency virus with antiretroviral therapy, suppressed viral load and condom use: A systematic review. CMAJ. 2018;190(46):E1350-60.

32. Castro KG, Ward JW, Slutsker L, Buehler JW, Jaffe HW, Berkelman RL, et al. 1993 revised classification system for hiv infection and expanded surveillance case definition for aids among adolescents and adults. Clin Infect Dis. 1993;17(4):802-10.

33. Rutstein S. Steps to constructing the new DHS Wealth Index [Internet]. DHS Program; Available from: https://dhsprogram. com/programming/wealth index/Steps_to_constructing_the_ new_DHS_Wealth_Index.pdf

34. Nagata JM, Magerenge RO, Young SL, Oguta JO, Weiser SD, Cohen CR. Social determinants, lived experiences, and consequences of household food insecurity among persons living with HIV/AIDS on the shore of Lake Victoria. Kenya AIDS Care. 2012;24(6):728-36.

35. Tuthill E, Maltby A, Conteh J, Sheira L, Miller J, Onono M, et al. Persistent food insecurity, but not HIV, is associated with depressive symptoms among perinatal women in Kenya: a longitudinal perspective. AIDS Behav. 2021;25(3):847-55.

36. Wang M, Miller JD, Collins SM, Santoso MV, Wekesa P, Okochi $\mathrm{H}$, et al. Social support mitigates negative impact of food insecurity on antiretroviral adherence among postpartum women in Western Kenya. AIDS Behav. 2021;24(10):2885-94.

37. Hannah DM, Lynch I, Mao F, Miller JD, Young SL, Krause $\mathrm{S}$. Water and sanitation for all in a pandemic. Nat Sustain. 2020;3(10):773-5.

38. Young SL, Boateng GO, Jamaluddine Z, Miller JD, Frongillo EA, Neilands TB, et al. The household water insecurity experiences (HWISE) scale: development and validation of a household water insecurity measure for low-income and middleincome countries. BMJ Glob Heal. 2019;4(5):e001750.

39. Wutich A, Brewis A, Tsai A. Water and mental health. WIREs. Water. 2020;7(5):e1461.

40. Geere J-AL, Hunter PR, Jagals P. Domestic water carrying and its implications for health: a review and mixed methods pilot study in Limpopo Province. South Africa Environ Heal. 2010;9(1):52.

41. Venkataramanan V, Geere JAL, Thomae B, Stoler J, Hunter PR, Young SL. In pursuit of â safe' water: The burden of personal injury from water fetching in 21 low-income and middle-income countries. BMJ Glob Heal. 2020;5(10):e003328.

42. Prabhu S, Harwell JI, Kumarasamy N. Advanced HIV: diagnosis, treatment, and prevention. Lancet HIV. 2019;6(8):e540-51.

43. Sijbesma C, Verhagen J, Nanavaty R, James AJ. Impacts of domestic water supply on gender and income: Results from a participatory study in a drought-prone region in Gujarat. India Water Policy. 2009;11(1):95-105.

44. Ngwenya BN, Kgathi DL. HIV/AIDS and access to water: A case study of home-based care in Ngamiland. Botswana Phys Chem Earth. 2006;31(15-16):669-80.

Publisher's Note Springer Nature remains neutral with regard to jurisdictional claims in published maps and institutional affiliations. 